\title{
SIMULATING THE RESIDENTIAL DEVELOPMENT OF RURAL RECREATION AREAS
}

Raymond J. Burby, III, Thomas G. Donnelly, and Shirley F. Weiss*

Accompanying the rapid increase in outdoor recreation over the past twenty-five years has been an equally significant growth in the development of recreational communities on the periphery of most metropolitan a reas in the United States. ${ }^{1}$ The penetration of thousands of recreation-oriented households into the rural hinterlands of metropolitan a reas poses a number of serious environmental and service problems for affected local governmental units. The research presented in this paper examines factors influencing residential location in reservoir recreation areas and proposes a computer model for simulating residential development patterns. The model provides planners and policy makers with a useful tool for anticipating problems and needs occasioned by vacation home development and policy guidance required to control development and maintain the quality of the environment.

Factors Influencing Shoreline and Surrounding Area Residential Location

Prior to programming the simulation model, intensive analyses were conducted to: (1) isolate a set of key variables associated with the location of residential development in reservoir areas; (2) determine the extent to which shoreline and surrounding area development patterns were the result of different locational influence factors; and (3) evaluate the generality of empirical relationships between influence factors and development patterns.

\section{Reservoir Study Areas}

Data for these analyses were secured for two reservoir areas in the Southeast, Lake Norman, North Carolina, and Lake Sidney Lanier, Georgia.

Lake Norman, which is owned and operated by the Duke Power Company, is located 15 miles northwest of Charlotte, North Carolina. Impounded by the Cowan's Ford Dam on the Catawba River in 1962, the Lake has a water surfacearea of 32,510 acres, with 520 miles of shoreline extending over portions of four counties. By 1969 Lake Norman had attracted 2,421 shoreline dwelling units. Lake Sidney Lanier, which is located 35 miles northwest of Atlanta, Georgia, has been the most popular Corps of Engineers reservoir in the Nation since 1964. Annual visitation now exceeds 11 million. Created in 1967 by the Buford Dam on the Chattahoochee River, Lake Lanier has 38,000 surface acres and 540 miles of shoreline extending over portions of five counties. By 1969 it had attracted 3,183 shoreline dwelling units, and had over 12, 000 lots available in shoreline subdivisions.

*Dr. Burby is a Senior Research Associate at the Center for Urban and Regional Studies; Dr. Donnelly is a Senior Research Associate at the Center for Urban and Regional Studies; and Dr. Weiss is an Associate Professor in the Department of City and Regional Planning and Associate Research Director of the Center for Urban and Regional Studies, University of North Carolina at Chapel Hill.

** This paperdraws on research whichwas supported in part by a matching grant from the Office of Water Resources Research, U.S. Department of the Interior and the Water Resources Research Institute of the University of North Carolina (OWRR Project No. B-0120NC). Prepared for presentation at the Annual Meeting of the Southern RegionalScience Association, April 13-14, 1972, the paper has been condensed substantially for publication in The Review. 
The study area for each reservoir was defined to include the entire reservoir shoreline and all land lying within approximately $2 \frac{1}{2}$ miles of the shoreline at the reservoir's full poolelevation. To provide an aerial base for measuring the extent of residential development and factors influencingdevelopment patterns, each study area was divided into small zones or cells. These cells were created by superimposing a grid over each reservoir a rea. The cells in the grid are squares, each 1, 000 feet on a side, containing approximately 23 acres. Therewere 8,661 grid cells in the Lake Norman study area and 10,936 cells in the Lake Lanier study area.

\section{$\underline{\text { Residential Land Use }}$}

Land in residential use was measured in each reservoir study area priorior to reservoir impoundment and again in the summer of 1969. The ninepoint scale utilized for this purpose was constructed by dividing each grid cell into nine equal parts, with each "ninth" equal to 2.55 acres. The amount of development in each cell was then computed by summing the number of residential ninths lying within the cell.

Because the reservoir study areas encompassed urban and rural as well as recreational residential land, residential land use was classified in terms of its orientation to the reservoir shoreline. On the basis of interviews with reservoir management personnel and preliminary observations of land use patterns in each study area, recreational shoreline residential development was defined as all residential land developed after the impoundment of each reservoir and lying within 300 feet of the shoreline. Residential development not fitting this description was grouped into a category te rmed "surrounding area residential use," including residential land within 300 feet of the shoreline which was developed prior to the impoundment of each reservoir and all residential landlocated more than 300 feet from the shoreline, regardless of the data of development.

\section{Attractiveness Factors}

Whether a grid cell was developed for residential use or remained vacant after reservoir impoundment was viewed as a function of its relative attractiveness for development. The first phase of the research, whichinvolved interviews with reservoir owners, predevelopment landowners, developers, and households, focused on identifying pivotal attractiveness factors associated with their evaluation of land for development and residential use. 2 The factors were then screened to determine those which: (1) could be coded in terms of a grid coordinate system; (2) were available in measurable form in local information systems or could be secured at a reasonable expense through field surveys; and (3) showed a sufficient range of variation for statistical analysis.

Variables which emerged from the se preliminary screenings were measured as they existed the year before impoundment. In several cases, they were utilized to identify changes which occurred in the study areas between impoundment and 1969.

\section{Results of the Analysis}

Statistical analyses of variables to serve as indicators of the attractiveness of land for residential use were based on a stepwise linear regression program. The order in which variables were entered into the program was controlled by the statistical significance ( $F$ value) of the variable in intermediate partial regression equations. Final equations were selected when the regression coefficients of additionalvariables were no longer significant at the .05 level. Results of the multivariate tests are presented in Table 1. 
TABLE 1. RELATIVE INFLUENCE OF MIXES OF ATTRACTIVENESS FACTORS IN EXPLAINING LOCATION OF RESIDENTIAL DEVELOPMENT

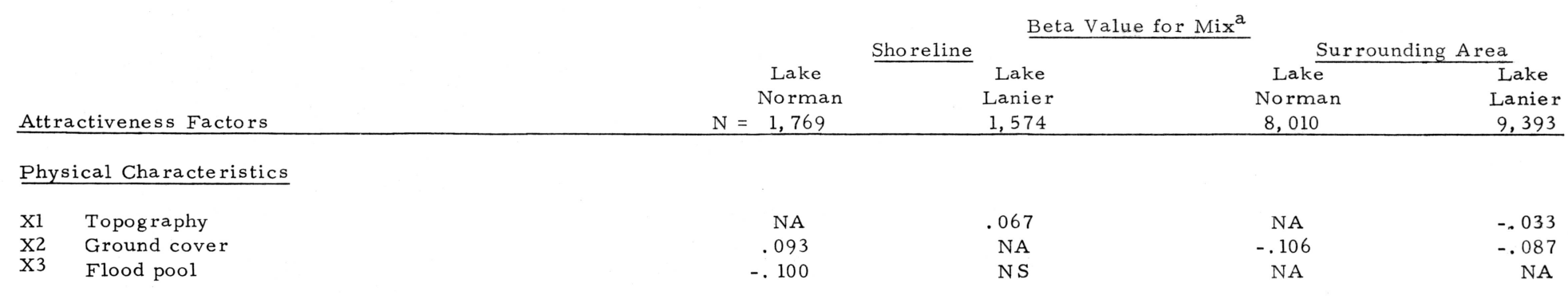

\section{Accessibility to Reservoir}

X4 Aerial distance to shoreline

X5 Road distance to nearest launch ramp

$\mathrm{X} 6$ Water distance to nea rest marina

$\mathrm{X} 7 \quad$ View of reservoir

X8 Peninsula location

$\mathrm{X} 9$ Access to shoreline

$\mathrm{X} 10$ Access to reservoir reservation

X11 Aerial distance from reservoir reservation

to shoreline

$\begin{array}{rc}\text { NA } & \text { NA } \\ -.129 & \text { NS } \\ \text { N S } & \text { NS } \\ \text { NA } & \text { NA } \\ .151 & .111 \\ .157 & \text { NS } \\ \text { N S } & .101 \\ & \\ \text { NS } & -.099\end{array}$

NS

NS

NA

NS

NA

NA

NA

NA
NS

$-.032$

NA

$-.064$

NA

NA

NA

NA 
TABLE 1. RELATIVE INFLUENCE OF MIXES OF ATTRACTIVENESS FACTORS IN EXPLAINING LOCATION OF RESIDENTIAL DEVELOPMENT

Continued

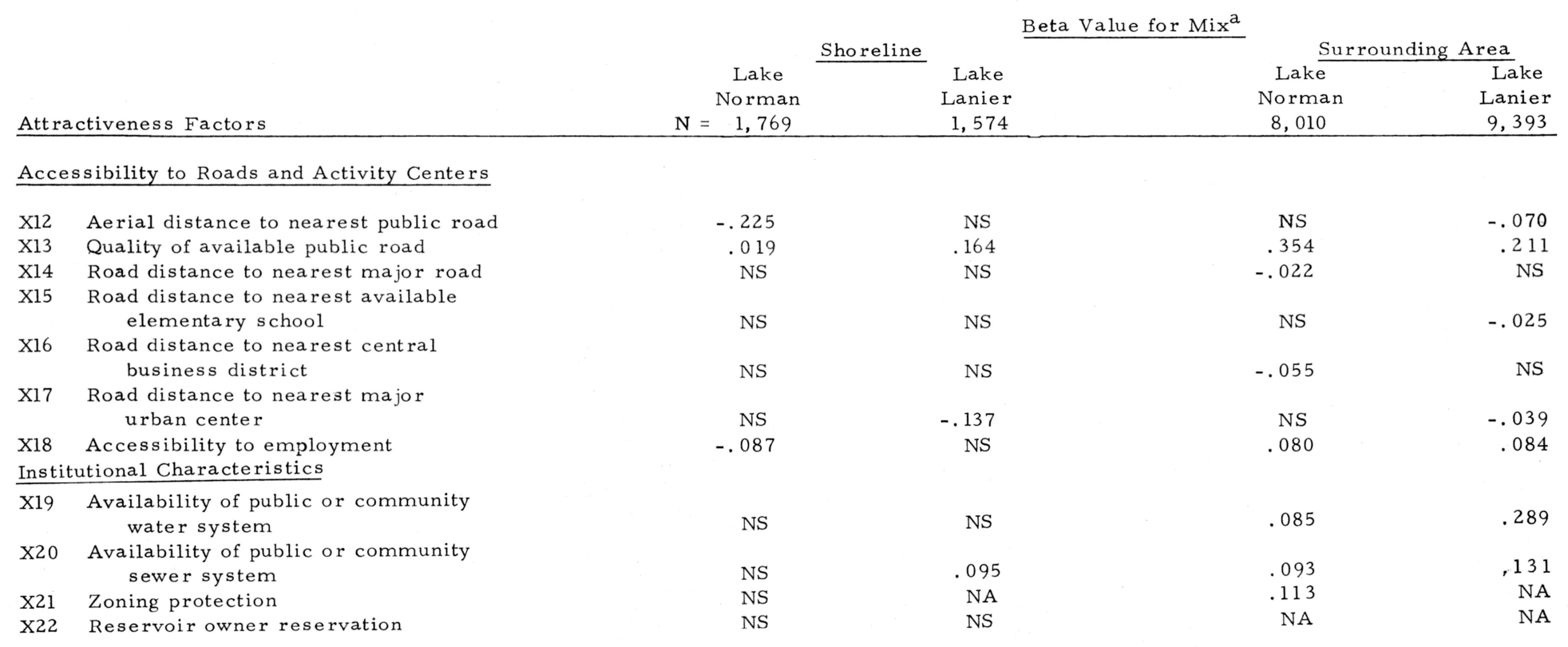


TABLE 1. RELATIVE INFLUENCE OF MIXES OF ATTRACTIVENESS FACTORS IN EXPLAINING LOCATION OF RESIDENTIAL DEVELOPMENT

Continued

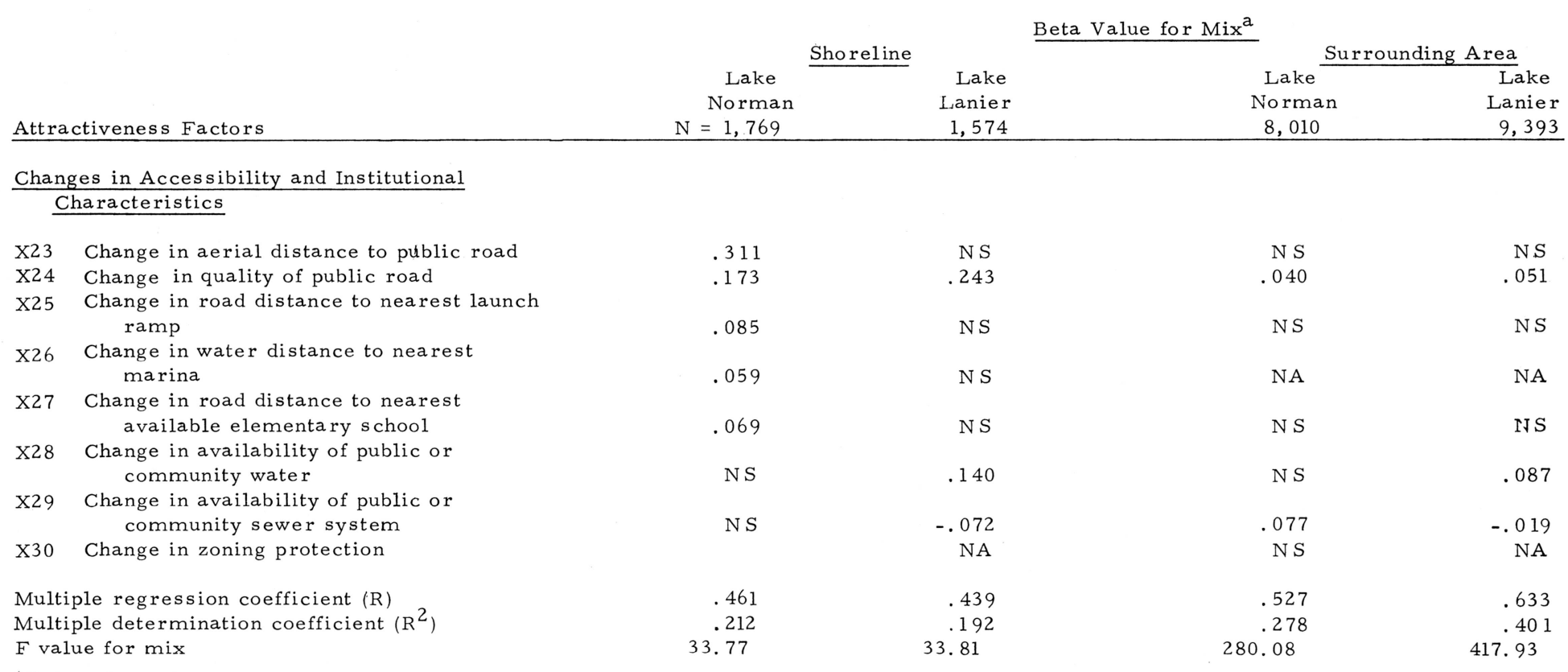

a Beta values given in table are significant at .05 leve1 or better.

NS = Not significant at .05 level ( $F$ value of 4$)$.

$\mathrm{NA}=$ Data not available or not applicable to class of land use. 
Two conclusions wereapparent from these tests: (1) recreational shoreline and surrounding area residential development represent highly differentiated markets in which the attractiveness of land for residential use is determined by different factors; and (2) the relationship between attractiveness factors and both shoreline and surrounding area residentiallocation is highly dependent on contextual characteristics which vary between the reservoir study areas.

Differences between factors influencing shoreline and surrounding a rea development patterns were clearcut. Land which tended to receive seasonal shoreline development was more accessible to reservoir recreation facilities, closer to the shoreline or reservoir reservations of these impoundments, at the tips of peninsulas, and located near roads and water systems which were built after the reservoirs were created. On the other hand, physical constraints on development, such as topography and ground cover; facilities existing prior to reservoir impoundment, such as utility systems; and the relative accessibility of land to such activity centers as elementary schools, business districts, and employment a reas generally hadlittle effect on the location of shoreline residential land use.

This was not the case with permanent residential development in the regions surrounding the study reservoirs. The location of surrounding area development was strongly influenced by the physical capability of land (gentle slopes and lack of ground cover), its relative accessibility to road networks, schools, and employment areas existing prior to reservoir impoundment, availability of utility systems, and accessibility to business districts and major urban centers. The distance of surrounding area land to the study reservoirs, availability of a view of the reservoir, accessibility to recreation facilities, changes in the availability of utilities, and changes in accessibility to roads and schools, however, hadless influence on the residential attractiveness of off-lake land.

In sum, these tests indicated that to simulate reservoir area residential use patterns, seasonal shoreline and permanent surrounding area residential development should be disaggregated, with cells in the study area assigned separate attractiveness indices for each form of development. The tests also indicated that factors influencing the attractiveness of land for development differed between the study reservoirs. Varying physiographic characteristics, differences in the pattern of urbanization at the time the reservoirs were impounded, and varying reservoir owner and local policy measures resulted in different arrays of factors influencing development patterns in each reservoir a rea. Because of interaction between contextual and attractiveness factors, there were also different orders of association for those factors which were common to both areas.

A Model for Simulating the Residential Development Of Reservior Recreation Areas

The proposed simulation model is an adaptation of the Chapin-WeissDonnelly Probabilistic Model for Residential Growth. ${ }^{3}$ The model simulates reservoir area residential location decisions through a randomizing procedure in which households are assigned to sites on the basis of the supply of land available and its attractiveness for recreational and permanent residential use. Operating on inputs describing the amount of vacant land in a cell, its attractiveness for development, and the total number of ninths of development to be allocated, the computer program selects a unit of development, sequentially examines each cell, notes the combined effect of the amount of vacant land and its attractiveness for development, and decides on a probabilistic basis whether or not the unit of development is allocated to that cell. This process is then repeated until each unit of development has been distributed. 
A probabilistic rather than deterministic method of allocating residential ninths was selected to take into account the complexity of land development decision sequences and the fact that variables influencing decision outcomes could neither be precisely determined nor measured. This procedure utilizes a form of linear sampling proportional to size without replacement. Each grid cell in a reservoir planning area is assigned a weight which represents the combined influence of the attractiveness of the cell for residential use and the amount of vacant land which is available to receive development. Weights for each cell are then summed across all cells and numbered sequentially. The resulting series of numbers can be regarded as a line whose total length equals the sum of the individual cell weights. Each segment of the line is associated with a cell, with the length of the segment representing the "weight" of the cell. For each ninth of development to be allocated, a random number falling within the total of the summed cell weights is generated. The random number locates the cell to which one unit of development is allocated.

In order to compare results obtained from the model with actual development, an ex post facto research design was followed. The model was programmed to "forecast" the 1969 distribution of residential development in each reservoir area starting from a point one year prior to reservoir impoundment: Lake Norman, 1961; and Lake Sidney Lanie r, 1956.

\section{Program for the Model}

The program for the land development simulation was developed in two steps. The first prepared the data for the simulation, while the second executed the simulation program.

Data preparation involved processing and storing on magnetic tape data describing the supply of vacant land, the attractiveness of land for development, and the total number of residential units to be allocated (residential growth). The supply of vacant land capable of receiving development over the forecast periodwas determined from land use and land capability analyses of the Lake Norman and Lake Sidney Lanier study areas at the start of the forecast period. These studies established the location of land preempted by existing urban and rural development and land programmed for inundation and other project-related uses by the reservoir owners.

Since land in these categories could not be developed for residential use, it was removed from the inventory of ninths of cell available for development. With these deductions the inventory of ninths of vacant land totaled 71,008 at the start of the Lake Norman forecast period in 1961, and 76, 111 at the start of the Lake Sidney Lanier forecast period in 1956. Thesetotals were many times greater than the actual number of residential ninths developed in each reservoir study area, so that the land supply was more than adequate to accommodate the residential growth to be allocated by the model. 4

Indices of the attractiveness per ninth of cell for residential development were constructed from key variables isolated by the multiple regression analyses reported above. To facilitate operational applications of the model, the number of attractiveness factors utilized in the indices were reduced by eliminating variables which, though statistically significant, contributed very little to the regression equations, and variables, such as those relating to road location, which were more appropriate as indicators of the suitability of vacant land for residential use. Computation of the attractiveness index for each cell involved three steps. First, empirical values of the attractiveness factors were substituted into an appropriate regression equation. Next, the distribution of values obtained from the regression equations was categorized into 14 groups of approximately equal size. Finally, the attractiveness score of each cell (and its component vacant ninths) was record- 
ed as an integer, from 1 to 14 , with 1 representing the smallest values obtained by substituting into the regression equations and, therefore, the lowest level of attractiveness for development in the simulation model.

Residential ninths to be allocated by the model were made to coincide with the actual increase in ninths of residential development which took place in the Lake Norman study area during the period 1961 through 1969 and in the Lake Sidney Lanier study area during the period 1956 through 1969. For the Lake Norman study area, the model was programmed to allocate 1, 057 ninths of residential development (733 shoreline ninths and 324 surrounding area ninths) in three iterations of three years each. In the case of the Lake Sidney Lanier study area, the model was programmed to allocate 1, 483 ninths of residential development (521 shoreline ninths and 962 surrounding a rea ninths) in five iterations, including an initial two-year iteration followed by four iterations of three years each.

Phase two of the computer program executed the simulation process. First, residential growth to be allocated was labeled in terms of vacant land categories and growth periods. Next, a cell capable of receiving development (assigned to the appropriate vacant land category) was randomly selected and the number of ninths of development assigned to that vacant land category (see footnote 4 ) was made available to the simulation process. The attractiveness weight of each cell (attractiveness per ninth $x$ ninths of vacant land) was summed to form a total attractiveness weight for all cells in the vacant land category. Random numbers between 1 and the total attractiveness weight were then generated and sorted to form an array of numbers in increasing order. Following this step, the attractiveness of eachcell in a vacant land category was consecutively and cumulatively (beginning with cell weight $0-n$ ) compared to a random number, which was selected consecutively from the ordered set of random numbers generated for the vacant land category. If the random number was less than the cumulative attractiveness associated with the cell and if the cell contained available land in the appropriate vacant land category, a ninth of development was allocated. If the random number was greater than the cumulative attractiveness of the cell, the individual attractiveness weights of successive cells were added to the running cumulative attractiveness until the ninth of development was allocated. Following the allocation of each ninth, the amount of development assigned to the growth period and vacant land category was reduced by one ninth, and both the supply of land available for development and attractiveness weight of the cell receiving growth was appropriately reduced. The simulation process was then repeated until each ninth assigned a vacant land category had been allocated.

Output of the Model

The results of test runs of the model for the Lake Norman and Lake Sidney Lanier study areas are summarized in Figures 1 and 2, which, for comparative purposes, also include the actual distribution of residential development at end of the forecast period (1969). The output of the simulation process is expressed in terms of the number of ninths of residential development allocated to each cell over the simulated growth periods. Blank cells indicate that no growth was allocated.

Because the simulation process contains a probabilistic element, the distribution of expected ninths of development varies for each run of the model. In the final tests reported here, 20 consecutive simulations were performed for each reservoir study area to evaluate the consistency of the output over repeated model runs. The median simulation, in terms of the sum of the squares of deviation between actual and allocated growth, was selected 


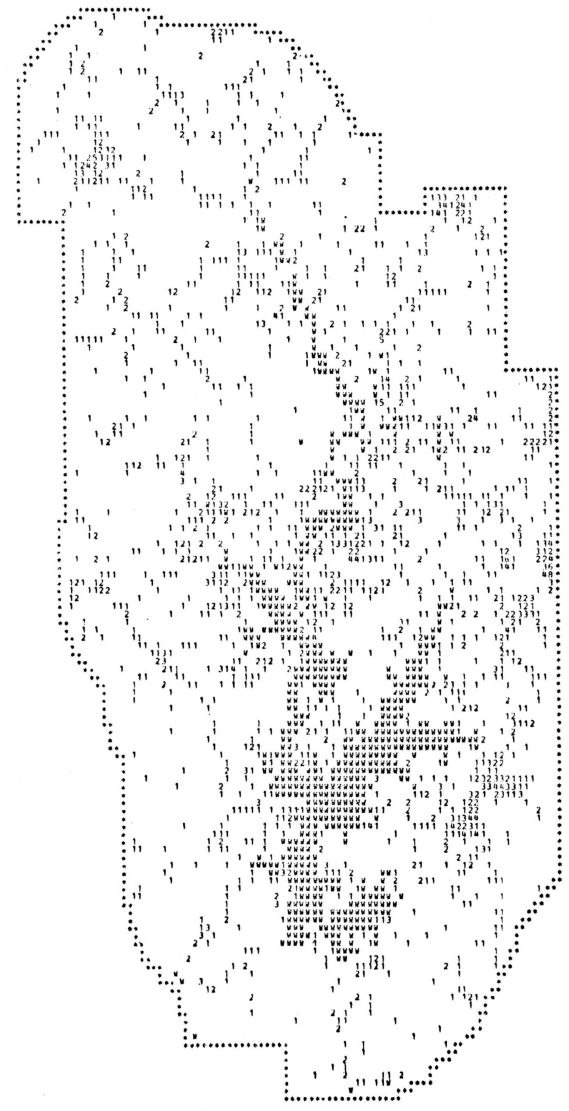

Simulated Residential Development, 1969 (Measured In Ninths Of Cell)

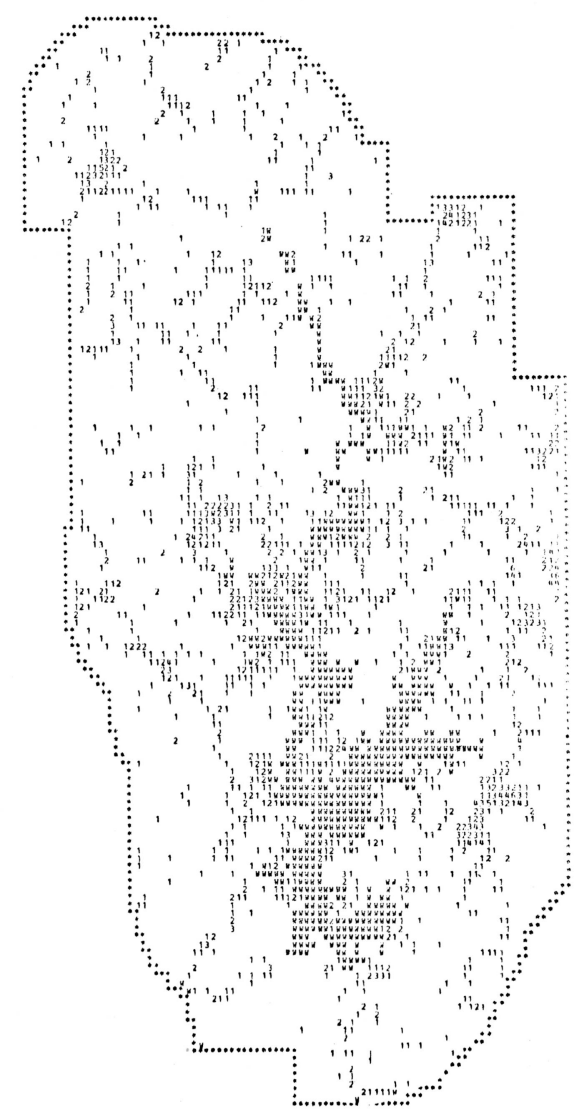

Actual Recidential Development, 1969 (Measured in Ninths Of Celi)

FIGURE 1. SIMULATION OF RESIDENTIAL DEVELOPMENT, LAKE NORMAN, NORTH CAROLINA, RESERVOIR STUDY AREA, 1961 - 1969.

One Cell $=1000^{\prime} \times 1000^{\prime}$

One Ninth $=2.55$ Acres 


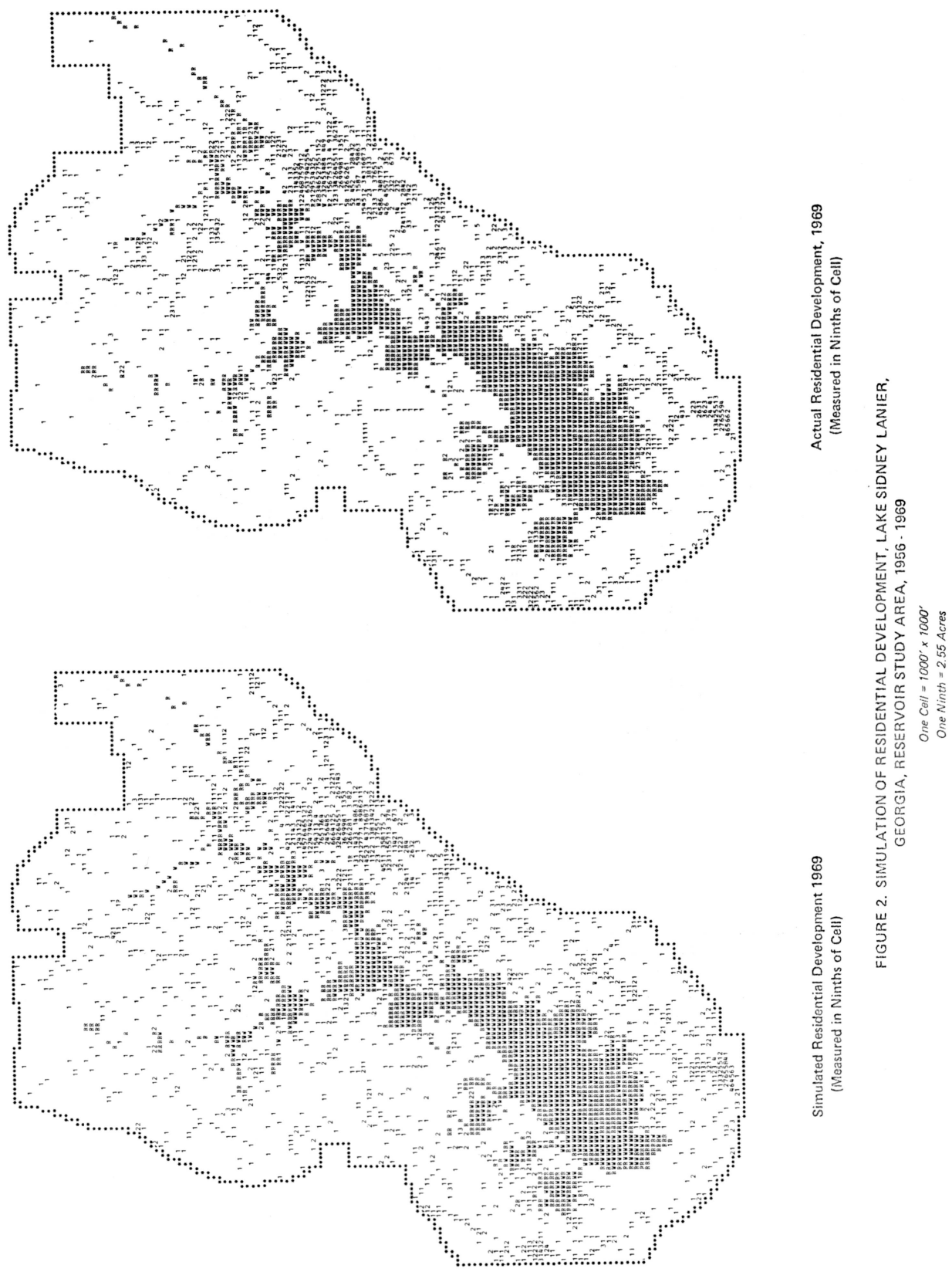


TABLE 2. COMPARISON OF SUMS OF SQUARES OF DEVIATION FOR EACH OF 20 CONSECUTIVE RUNS, PROBABILISTIC MODEL FOR FORECASTING RESIDENTIAL DEVELOPMENT, LAKE NORMAN, NORTH CAROLINA, RESERVIOR AREA, 1961-1969 AND LAKE SIDNEY LANIER, GEORGIA, RESERVOIR AREA, $1956-1969$

Total

Sum of

Squares

1,952

1,970

1,996

2,036

2,042

2,046

2,052

2,062

2,072

2,078

2,082

, 092

2,098

2,098

2,112

2,122

2,128

2,140

2,150

2,162
Lake Norman

Mean Sum of Squares

All Cells

Developed

0.245
0.247
0.251
0.256
0.256

0.257
0.258
0.259
0.260
0.261

0.261
0.263
0.264
0.264
0.265

0.266
0.267
0.269
0.270
0.272

Cells

1.609

1.619

1.639

1.669

1.647

1.692

1.672

1.685

1.691

1.715

1.700

1.749

1.727

1.721

1.684

1.713

1.744

1.713

1.786

1.709

\section{Total}

Run Sum of

No. Squares

3,726

3, 744

3,760

3,768
3,776

3,778

3, 784

3,796

3,802
3,806

3, 808

3, 848

3,856

3,860

3,874

3, 882

3,886

3,910

3,924

3,982
Lake Sidney Lanier

Mean Sum of Squares

Developed

All Cells Cells

0.417

0.420

0.421

0.422

0.423

2.119

2.125

2.141

2.113

2.094

0.423

0.424

0.425

0.426

0.426

].
2.164
2.145

2. 109

2. 122

2.169

0.427

0.431

0.432

0.433

0.434

2.165

2.158

2.153

2.155

2.138

0.435

0.435

0.438

0.440

0.446

2.153

2. 182

2.160

2.185

2. 209
Run

No.

13

18

6

12

7

15

20

14

3

1
10 
to represent the expected pattern of residential development reported in Figures 1 and 2 .

\section{Evaluation of the Model}

Test runs of the modelwere evaluated in terms of the efficiency of the program, consistency of the output between consecutive runs and runs in each study area, and, most importantly, in terms of the deviation of the simulation from actual development patterns.

Efficiency of the Program

The program for simulating residential development was very efficient. Each complete simulation, involving generating and sorting random numbers, searching the working simulation map to allocate development, making appropriate bookkeeping entries, and calculating the criterion sum of squares of deviation between allocated and actual growth, required 3 seconds of IBM $360 / 75$ computer time for Lake Norman and 7 seconds for Lake Sidney Lanier. An additional 14 to 15 seconds were required to print the set of computer maps describing the median simulation in each series of runs.

\section{Consistency of the Ouput}

The sum of squares of deviation between actual growth and allocated growth over the forecast periods was utilized as a criterion to evaluate the consistency of the modelover repeated simulation runs. In the 20 consecutive simulations performed for the final tests of the model, the criterion values traced out a smooth curve, indicating that the linear technique performed satisfactorily. These values ranged from 1,952 to 2,162 in 20 runs for the Lake Norman study area and from 3,726 to 3,982 in an identical number of runs for the Lake Sidney Lanier study area. (See Table 2.)

To compare the results of test runs for Lake Norman and Lake Sidney Lanier, the mean sum of squares of the deviation between actual and simulated growth was calculated both in terms of all cells capable of receiving development and only those cells allocated or actually receiving ninths of development over the forecast periods. As indicated in Table 2, the simulation model performed adequately for each reservoir study area, though the Lake Norman simulations were slightly more accurate. The mean square deviation from actual development over all cells ranged from .245 to .272 ninths per cell for the Lake Norman simulations and from . 417 to . 446 ninths per cell for the Lake Sidney Lanier simulations.

\section{CONCLUSIONS}

The simulation model provides planners and policy makers with a useful tool to evaluate the effects of policy alternatives on reservoir a rea development patterns and forecast the probable location of residentialgrowth. 8 Realization of the model's potential as a planning tool depends on both the concern of reservoir owners and local officials for the quality of the environment and the provision of a suitable institutional framework for reservoir arsa planning.

Achievement of these preconditions for planning will not be easy. With the exception of the Tennessee Valley Authority, reservoir developing agencies have only recently begun to consider the impact of water impoundments on adjacent land use. Rural jurisdictions in which most multipurpose reservoirs are constructed lack the financial and technical resources, and often the inclination, to initiate comprehensive planning and land use regulations to control residential development. Furthermore, since large impoundments 
invariably cross jurisdictional boundaries, intergovernmental coordination is required among local governmental units which often have little relevant experience in cooperative undertakings. Until these problems a re overcome and adequate planning for surrounding public and private land uses are incorporated into the process of planning and developing water impoundments, long run environmental deterioration can be expected. By providing a basis for an operational planning methodology in reservoir recreation areas, it is hoped that the present research will help change the expected outcome and lead to a sustained improvement in environmental quality. 


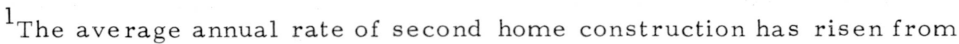
about 20,000 units per yearduring the 1940 's to 55, 000 units per year during the 1960's. See U.S. Bureau of the Census, Current Housing Reports, Series H-121, No. 16, Second Homes in the United States, Washington: U.S. Government Printing Office, 1969, p. 7. A significant proportionof the second home development in the Southeast appears to occur in the vicinity of large water impoundments. For example, in a recent survey by the authors over 60, 000 homes, summer cottages, and trailers have been identified adjacent to multipurpose reservoirs in Alabama, Florida, Georgia, Kentucky, Mississippi, North Carolina, South Carolina, Tennessee, Virginia, and West Virginia. For a discussion of factors influencing the residential utilization of multipurpose reservoirs see, Raymond J. Burby, III, Thomas G. Donnelly, and Shirley F. Weiss, Factors Influencing the Residential Utilization of Reservoir Shorelands in the Southeast, Report No. 44, Raleigh: Water Resources Research Institute of the University of North Carolina, December 1970.

2 The results of these interviews are summarized in the following reports: Raymond J. Burby, III, The Role of Reservoir Owner Policies in Guiding Reservoir Land Development, Report No. 29, Raleigh: Water Resources Research Institute of the University of North Carolina, November 1969; Raymond J. Burby, III, and Shirley F. Weiss, Public Policy and Shoreline Landowner Behavior, Report No. 38, Raleigh: Water Resources Research Institute of the University of North Carolina, July 1970; and Raymond J. Burby, III, Household Decision Processes in the Purchase and Use of Reservoir Recreation Land, Report No. 51, Raleigh: Water Resources Research Institute of the University of North Carolina, March 1971.

${ }^{3}$ For a report on the adaptation, see Raymond J. Burby, III, Thomas G. Donnelly, and Shirley E. Weiss, A Model for Simulating Residential Development in Reservoir Recreation Areas, Report No. 52, Raleigh: Water Resources Research Institute of the University of North Carolina, May 1971. For a summary of the original version of the model, see F. Stuart Chapin, Jr., and Shirley F. Weiss, "A Probabilistic Model for Residential Growth," Transportation Research, 2 (December 1968): 375-390.

${ }^{4} \mathrm{~A}$ second refinement to the vacant land inventory was carried out to give recognition to the key influence of the availability of a public road on the location of development. The fact that development almost always occurs adjacent to a road needs little elaboration. However, owing to the rural character of much of the reservoir study areas and corresponding low density of development, this factor assumes even moreimportance in reservoir area growth than in urban a rea residential development. Accordingly, the inventories of shoreline and surrounding area vacant land, and later the inventory of ninths to be allocated, were categorized by the existence or absence of roads in a cell prior to impoundment and roads constructed during the forecast periods.

${ }^{5}$ The choice of the median run rather than an "average" allocation for the ex post facto forecast was made for two reasons. First, to be meaningful, averaging would have required that the output be expressed in terms of tenths of a ninth (1/90 of a cell). This fine grain would have exceeded the level of detail of the input data. More important, however, is the fact that in rounding the results to the nearest ninth, it would be extremely unlikely that the total ninths allocated in an "average" forecast would match the control totals specified in the model inputs. 